is specific for compounds of the ribulose configuration and does not act on xylulose (Cohen, 1953). All the pentulose detectable in the cysteine-carbazole reaction was converted into aldopentose. It may be noted that the specific enzyme is an elegant tool in distinguishing the pentuloses and in permitting the estimation of one in the presence of the other. The same enzyme may also be applied to the specific estimation of $\mathrm{L}$-fucose, which is converted into L-fuculose (Green \& Cohen, 1956).

Since no evidence was obtained for pentulose other than ribulose, and this compound was isolated in the form of pentulose phosphate as the only product of the degradation of 6-phosphogluconate, it has been concluded that the primary product which could be isolated after degradation of PG by the dehydrogenase of Esch. coli was ribulose phosphate, as has been observed for the PG dehydrogenases of yeast and liver.

\section{SUMMARY}

1. A purified 6-phosphogluconate dehydrogenase was prepared from extracts of Escherichia coli B. This preparation was very low in phosphatase, pentose phosphate isomerase and transketolase or other ribose phosphate-splitting enzymes.

2. After action of the enzyme on phosphogluconate, the reaction mixture was fractionated on an ion-exchange column. Ribulose 5-phosphate was isolated in high yield. It was dephosphorylated, and the free ribulose was enzymically converted into D-arabinose, which was isolated as the characteristic D-arabinose diphenylhydrazone.
The work described in this paper was conducted under a grant from the Commonwealth Fund.

\section{REFERENCES}

Cohen, S. S. (1953). J. biol. Chem. 201, 71.

Cohen, S. S. \& Scott, D. B. McN. (1950). Science, 111, 543.

Cori, G. T., Slein, M. W. \& Cori, C. F. (1948). J. biol. Chem. 173, 605.

Dickens, F. (1938). Biochem. J. 32, 1626.

Dische, Z. \& Borenfreund, E. (1951). J. biol. Chem. 192, 583.

Glatthaar, C. \& Reichstein, T. (1935). Helv. chim. acta, 18, 80.

Green, M. \& Cohen, S. S. (1956). J. biol. Chem. 219, 557.

Groth, D. P., Mueller, G. C. \& LePage, G. A. (1952). J. biol. Chem. 199, 389.

Hochster, R. M. (1955). Canad. J. Microbiol. 1, 346.

Horecker, B. L., Smyrniotis, P. Z. \& Seegmiller, J. E. (1951). J. biol. Chem. 193, 383.

King, E. J. (1932). Biochem. J. 26, 292.

Kornberg, A. \& Pricer, W. E. (1951). J. biol. Chem. 193, 481.

LePage, G. A. \& Mueller, G. C. (1949). J. biol. Chem. 180, 975.

Miller, G. L., Golder, R. H. \& Miller, E. E. (1951). Analyt. Chem. 23, 903.

Scott, D. B. McN. (1956). Biochem. J. 63, 593.

Scott, D. B. McN. \& Cohen, S. S. (1951). J. biol. Chem. 188, 509.

Scott, D. B. McN. \& Cohen, S. S. (1953). Biochem. J. 55, 23.

Seegmiller, J. E. \& Horecker, B. L. (1951). J. biol. Chem. $192,175$.

Stumpf, P. K. \& Horecker, B. L. (1956). J. biol. Chem. 218, 753.

Warburg, O., Christian, W. \& Griese, W. (1935). Biochem. Z. 282, 157.

\title{
Studies on the Composition of Lipids of the Rabbit
}

\author{
By J. H. FUTTER AND F. B. SHORLAND \\ Fats Research Laboratory, Department of Scientific and Industrial Research, Wellington, New Zealand
}

(Received 26 June 1956)

Of the pasture-fed animals the wild rabbit has a special interest, because linolenic acid, the main dietary fatty constituent, forms over $40 \%$ af the fatty tissues as compared with less than $1 \%$ found in the depot fats of ruminants (Shorland, 1953). Earlier studies on pasture-fed horses, which also contain a high proportion (about $16 \%$ ) of linolenic acid in their fatty tissues (Brooker \& Shorland, 1950; Gupta \& Hilditch, 1951) have shown that this acid is differentially distributed between the tissue lipids (Shorland, Bruce \& Jessop, 1952). Whereas the glyceride fractions contain trienoic (linolenic) acid as the main $\mathrm{C}_{18}$ unsaturated fatty acid, in the phospholipid $\mathrm{C}_{18}$ unsaturated fatty acids dienoic constituents predominate. In this paper we report a similar study on the lipids of the rabbit.

\section{EXPERIMENTAL}

The rabbits used in this work were trapped on 6 and 7 June 1951 (mid-winter), in the Guavas Forest area, near Waipawa, Hawkes Bay, New Zealand, by officers of the Animal Ecology Section of the Department of Scientific and Industrial Research, New Zealand. There were twenty-five males, average wt. 1575 s.D. \pm 135 g., and eighteen females, average wt. 1499 s.D. $\pm 160 \mathrm{~g}$. A few of the females were in the early stages of pregnancy and almost all of the rabbits 
had a thin layer of fatty tissue in the abdominal cavity. In rabbits trapped six months earlier such fat was not visible, and at that stage many of the females had young litters.

The traps were set in the evening and the rabbits collected at dawn. With the least possible delay the following tissues were removed: liver, kidney, longissimus dorsi muscle and fatty tissue from the abdominal cavity. The corresponding material from the males and females was bulked separately, finely sliced, and sterilized by dropping into boiling ethanol and holding at boiling point for about $15 \mathrm{~min}$. With the longissimus dorsi muscle the whole sample was not used, but a representative portion was taken. In addition to the samples just described, yellow abdominal fat was separated from two male rabbits and one female from another collection, to compare this fat with the white fat usually encountered.

The extraction of the lipids from the tissues, and the separation of glyceride and phospholipid fractions, were carried out essentially as described by Shorland et al. (1952). Small amounts of phospholipids remaining in the glycerides were, however, removed by passing a chloroform solution of the fraction through a silica gel column as described by Borgström (1952).

By elution with chloroform it was possible to recover almost completely the non-phospholipid constituents while retaining the phospholipids on the column. The phospholipids were subsequently removed with methanol and added to the phospholipids earlier separated by their insolubility in acetone. The characteristics of the lipids before separation into phospholipids and glycerides are shown in Table 1.

In previous work it has been customary to refer to the acetone-soluble fraction as 'glycerides' (cf. Hilditch \& Shorland, 1937), though it is well appreciated that such fractions contain also cholesterol esters and perhaps wax esters. However, it appears that the unsaponifiable matter in animal-tissue fats consists largely of cholesterol present mainly in the free form (cf. Hilditch \& Shorland, 1937; Bloor, 1943). It is reasonable to suppose therefore that in the present investigation the acetone-soluble fraction will consist mainly of glycerides. It is proposed for convenience here to continue to use the term 'glycerides' to designate the acetone-soluble constituents, recognizing that in the present work, and indeed, in work on natural fats generally, the term glycerides does not imply the complete absence of sterol esters, wax esters and unsaponifiable constituents.

The ester-fractionation analyses were carried out as previously described by Shorland et al. (1952). In determining the mean unsaturation of the $\mathrm{C}_{20}$ unsaturated acids by the customary procedure of graphical extrapolation (cf. Hilditch, 1956) it became apparent that some polymerization had occurred during distillation. The mean unsaturation values shown in Table 2 are therefore probably lower than in the original lipid. The polymerization of the methyl esters of the $C_{22}$ unsaturated acids was even more extensive. To calculate the proportions of these acids it was therefore necessary to assign arbitrarily the same mean unsaturation as was found for the $\mathrm{C}_{20}$ unsaturated acids. Furthermore, because of the small amounts of lipids (5-10 g.) available in the non-fatty tissues, the traces of $\mathrm{C}_{22}$ unsaturated acids were. perhaps not detected in all instances, as it was not practicable to carry the ester fractionation far enough. The problem now described is, however, generally inherent in the ester-fractionation technique, and hence it is not uncommon to assign the $\mathrm{C}_{20}$ and above unsaturated acids to the $\mathrm{C}_{20}-\mathrm{C}_{22}$ group even though there is no direct evidence from the saponification equivalents of the methyl ester fractions for acids of higher molecular weight than $\mathrm{C}_{20}$. Examples of this kind are to be found in recent publications (cf. Hilditch, 1956). Therefore, in Table 2 the non-detection of $\mathrm{C}_{22}$ unsaturated acids does not necessarily imply their absence, but indicates merely that such acids, if present, occur in only minor proportions.

In calculating the proportions of saturated acids of higher molecular weight than stearic acid, it has been assumed that arachidic acid only is present, though the probable occurrence of acids of still higher molecular weight is fully recognized.

The composition of the $\mathrm{C}_{18}$ unsaturated acids was determined by the Brice \& Swain (1945) procedure, purified concentrates of methyl esters obtained during ester fractionation being used (see Table 2). The composition of the $\mathrm{C}_{20}$ unsaturated acids was not studied in detail owing to the difficulty in obtaining purified fractions. Nevertheless, through the application of the spectrophotometric procedure as described by Shorland \& Johannesson (1951), it was possible to estimate that the $\mathrm{C}_{20}$ unsaturated acids of the female liver 'glycerides' contained $14 \cdot 7 \%$ of pentaene and $22 \%$ of tetraene constituents, whereas for the liver phospholipid the corresponding values were 14.9 and $47.4 \%$ respectively. The absorption at $372 \mathrm{~m} \mu$. after alkali isomerization indicated the presence of some 1-2\% of hexaene acids in the $\mathrm{C}_{20}$ fractions, but the proportions of

\section{Table 1. Characteristics of lipid fractions}

The percentage of phospholipid was calculated from the $P$ content by multiplying by 25 . The free fatty acids are expressed as oleic acid, and the neutral fat was determined as the difference between the total lipids and the sum of the free fatty acids and phospholipids. M., Male; F., female.

\begin{tabular}{|c|c|c|c|c|c|c|}
\hline Origin of fat & $\begin{array}{l}\text { Average } \\
\text { wt. } \\
\text { (g.) }\end{array}$ & $\begin{array}{c}\text { Lipids in } \\
\text { tissue } \\
(\%)\end{array}$ & $\begin{array}{c}\text { Phospho- } \\
\text { lipids in } \\
\text { lipids } \\
(\%)\end{array}$ & $\begin{array}{l}\text { Unsaponifi- } \\
\text { able matter } \\
\text { in lipids } \\
(\%)\end{array}$ & $\begin{array}{l}\text { Free fatty } \\
\text { acids in } \\
\text { lipids } \\
(\%)\end{array}$ & $\begin{array}{c}\text { Neutral fat } \\
\text { in lipids } \\
(\%)\end{array}$ \\
\hline $\begin{array}{r}\text { Abdominal cavity } \mathbf{M} . \\
\text { F. }\end{array}$ & $\begin{array}{r}6 \cdot 2 \\
17 \cdot 6\end{array}$ & $\begin{array}{l}86 \cdot 0 \\
79 \cdot 6\end{array}$ & $\begin{array}{l}\text { Trace } \\
\text { Trace }\end{array}$ & $\begin{array}{l}0.2 \\
0.5\end{array}$ & $\begin{array}{l}\text { Trace } \\
\text { Trace }\end{array}$ & $\begin{array}{l}100 \cdot 0 \\
100 \cdot 0\end{array}$ \\
\hline Liver $\underset{\text { F. }}{\text { M. }}$ & $\begin{array}{l}40 \cdot 6 \\
29 \cdot 1\end{array}$ & $\begin{array}{l}4 \cdot 9 \\
4 \cdot 7\end{array}$ & $\begin{array}{l}40 \cdot 5 \\
39 \cdot 0\end{array}$ & $\begin{array}{l}13 \cdot 9 \\
18 \cdot 5\end{array}$ & $\begin{array}{l}9 \cdot 3 \\
2 \cdot 8\end{array}$ & $\begin{array}{l}50 \cdot 2 \\
58 \cdot 2\end{array}$ \\
\hline $\begin{array}{r}\text { Kidney } \\
\text { F. }\end{array}$ & $\begin{array}{l}11 \cdot 8 \\
10 \cdot 3\end{array}$ & $\begin{array}{l}3 \cdot 1 \\
5 \cdot 0\end{array}$ & $\begin{array}{l}31 \cdot 0 \\
29 \cdot 2\end{array}$ & $\begin{array}{l}23 \cdot 1 \\
12 \cdot 7\end{array}$ & $\begin{array}{l}4 \cdot 3 \\
3 \cdot 2\end{array}$ & $\begin{array}{l}64 \cdot 7 \\
67 \cdot 6\end{array}$ \\
\hline $\begin{array}{r}\text { Longissimus dorsi } \mathrm{M} \text {. } \\
\mathrm{F} .\end{array}$ & - & $\begin{array}{l}1 \cdot 9 \\
1 \cdot 5\end{array}$ & $\begin{array}{l}22 \cdot 3 \\
35 \cdot 7\end{array}$ & $\begin{array}{l}20 \cdot 3 \\
16 \cdot 2\end{array}$ & $\begin{array}{l}8 \cdot 4 \\
1 \cdot 3\end{array}$ & $\begin{array}{l}69 \cdot 3 \\
63 \cdot 0\end{array}$ \\
\hline
\end{tabular}


Table 2. Fatty acid composition of glycerides and phospholipids from the fatty tissues, liver, kidney and muscle of the rabbit

Fatty acids are expressed as a percentage $(w / w)$. The figures in parentheses indicate the mean unsaturation expressed in terms of hydrogen; the non-detection of $\mathrm{C}_{22}$ unsaturated acids is shown by an asterisk. M., Male; F., female.

Origin of fat

Abdominal cavity $\mathbf{M}$.

F.

'Yellow fat' Mixed M. \& F.

Liver M.

F.

Kidney M.

F.

Longissimus dorsi muscle $\mathrm{M}$.

F.

F. -

$18 \cdot 2$

Liver M.

F.

Kidney M.

F.

Longissimus dorsi muscle $\mathbf{M}$

F.
Saturated

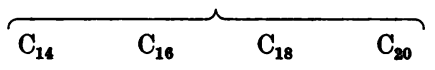

(a) Glycerides

$\begin{array}{llll}1.6 & 22.2 & 6.4 & 0.8\end{array}$

$1 \cdot 6 \quad 22 \cdot 2 \quad 5 \cdot 3$

$0 \cdot 7$

$0 \cdot 2 \quad 22 \cdot 7$

$6 \cdot 1$

Trace

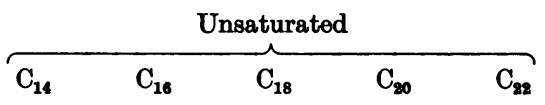

$\begin{array}{ccccc}0.4 & 4.4 & 62.9 & 1.3 & * \\ (2 \cdot 0 \mathrm{H}) & (2 \cdot 0 \mathrm{H}) & (4.8 \mathrm{H}) & (4.8 \mathrm{H}) & \\ 0.4 & 4 \cdot 1 & 65 \cdot 7 & \text { Trace } & * \\ (2 \cdot 0 \mathrm{H}) & (2 \cdot 0 \mathrm{H}) & (5 \cdot 1 \mathrm{H}) & & \end{array}$

Trace $\quad 7 \cdot 4 \quad 63.6 \quad$ Trace

$(2 \cdot 0 \mathrm{H}) \quad(4 \cdot 9 \mathrm{H})$

$\begin{array}{llllllccc}19.8 & 18.0 & 0.6 & - & 0.6 & 35 \cdot 6 & 21 \cdot 8 & 3.6 \\ (2 \cdot 0 \mathrm{H}) & (4 \cdot 3 \mathrm{H}) & (5 \cdot 8 \mathrm{H}) & (5 \cdot 8 \mathrm{H})\end{array}$

$21.8 \quad 8.9$
$-\quad 2.9$
$\begin{array}{ccccc}\text { Trace } & 3.2 & 48.0 & 13.3 & 1.9 \\ & (2.0 \mathrm{H}) & (3.5 \mathrm{H}) & (6.0 \mathrm{H}) & \text { (as } 6.0 \mathrm{H})\end{array}$

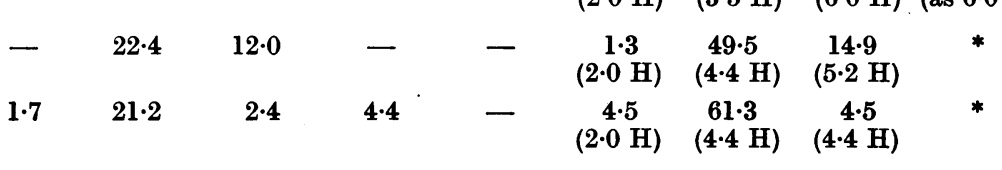

$\begin{array}{lll}8 \cdot 0 & 49 \cdot 6 \quad 18 \cdot 4\end{array}$

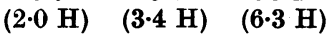

$4 \cdot 2 \quad 55 \cdot 0 \quad 13 \cdot 5$

$(2.0 \mathrm{H}) \quad(4 \cdot 3 \mathrm{H}) \quad(3.7 \mathrm{H})$

(b) Phospholipids

$\begin{array}{lll}10 \cdot 3 & 13 \cdot 1 & 18 \cdot 5\end{array}$

$\begin{array}{llll}1 \cdot 3 & 36 \cdot 0 & 18 \cdot 2 & 2 \cdot 6\end{array}$

$(2.0 \mathrm{H}) \quad(3.9 \mathrm{H}) \quad(5.2 \mathrm{H}) \quad($ as $5.2 \mathrm{H})$

$\begin{array}{lll}1 \cdot 1 & 42 \cdot 1 & 9 \cdot 8\end{array}$

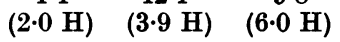

$\begin{array}{llll}1 \cdot 1 & 39 \cdot 4 & 20 \cdot 4 & 9 \cdot 3\end{array}$

$(2.0 \mathrm{H}) \quad(3.6 \mathrm{H}) \quad(5.5 \mathrm{H}) \quad($ as $5.5 \mathrm{H})$

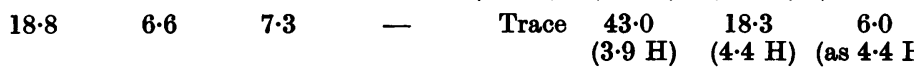

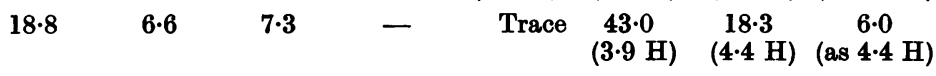

$\begin{array}{cccc}5 \cdot 2 & 34 \cdot 5 & 16 \cdot 1 & 7 \cdot 7 \\ (2 \cdot 0 \mathrm{H}) & (3.5 \mathrm{H}) & (3 \cdot 8 \mathrm{H}) & (\text { as } 3 \cdot 8 \mathrm{H})\end{array}$

$\begin{array}{llll}3.5 & 35 \cdot 1 & 20 \cdot 0 & 6 \cdot 2\end{array}$

$(2.0 \mathrm{H}) \quad(3.5 \mathrm{H}) \quad(5.6 \mathrm{H}) \quad($ as $5.6 \mathrm{H})$

* Not detected.

hexaene acids in the residual fractions containing $\mathrm{C}_{22}$ unsaturated acids could not be estimated satisfactorily owing to the extensive polymerization.

\section{DISCUSSION}

The composition of the fatty tissues of the wild rabbit has not hitherto been determined in detail, though Vickery (1928, quoted by Hilditch, 1956), found $5 \%$ of myristic, $23 \%$ of palmitic and $4 \%$ of stearic acids and $68 \%$ of unsaturated acids which were not completely identified. However, from the weight of ether-insoluble polybromides Hilditch (1956) estimated that nearly $20 \%$ of linolenic acid was present. Having regard to the analytical techniques then available, the results indicate a similar fatty acid composition to that shown for the fatty tissues in the present work (see Table 2). The high content $(37 \cdot 7-42.2 \%)$ of linolenic acid in the fatty tissue lipids (see Table 3) shows the ability of the rabbit to store this acid to a level approaching that found (about 60-70\%) in the dietary fat (Shorland, 1953). Comparison made between the fatty tissues of the male and female rabbits and of the yellow fat (see Tables 2 and 3) shows little difference in fatty acid composition, the palmitic acid content (about $22 \%$ ) in these samples being somewhat lower than usually found $(25-30 \%)$ in mammalian depot fats (cf. Hilditch, 1956).

The presence of substantial amounts (4.5-29.7\%) of $\mathrm{C}_{20}-\mathrm{C}_{22}$ unsaturated acids in non-fatty tissue lipids, which form the greater part of the total lipids 
in the rabbit, raises the question of their origin. It is known that the chief fatty constituent of the diet, linolenic acid, is transformed in the rat into pentaenoic and particularly hexaenoic acids (cf. Widmer \& Holman, 1950; Witten \& Holman, 1952). In poultry, on the other hand, Reiser $(1950,1951)$ considers that linolenic acid forms poly-unsaturated acids with from two to six double bonds. These findings are generally supported by Klenk (1955) with labelled acetate in conjunction with linoleic and linolenic acids. He considers that acetate is added at the carboxyl end with the introduction of new double bonds in the divinylmethane pattern.

The evidence as to the nature of the $\mathrm{C}_{20}-\mathrm{C}_{22}$ unsaturated acids in the non-fatty tissues of the rabbit is somewhat incomplete, though the occurrence of pentaenoic and hexaenoic acids consistent with the conversion of some of the dietary linolenic acid into these constituents was indicated. However, the mechanism for the formation of the less unsaturated $\mathrm{C}_{20}-\mathrm{C}_{22}$ acids cannot at present be indicated unless, in accordance with Reiser's $(1950,1951)$ findings on poultry, linolenic acid actually forms the complete range of higher unsaturated acids with from two to six double bonds.

The dependence of the fatty acid composition of non-ruminants on the nature of the dietary fat (cf. Shorland, 1950, 1952) is further shown by the fact that the perinephric and interscapular fats of the chinchilla rabbit fed on a diet of low fat content stored only $2 \cdot 0-3 \cdot 1 \%$ of linolenic acid, the main unsaturated fatty acid being oleic, which constituted 31.9-36.7 \% of the total fatty acids (Clément \& Meara, 1951).

Comparative studies on the fatty acid composition of 'glycerides' and phospholipids in mammals (Hilditch \& Shorland, 1937; Shorland et al. 1952); eggs (Shorland, 1951) and fish (Shorland \& Hilditch, 1938; Shorland, 1939; Oliver \& Shorland, 1948)

Table 3. Composition of the $\mathrm{C}_{18}$ unsaturated fatty acids of the 'glycerides' and phospholipids from the fatty tissues, liver, kidney and muscle of the rabbit

Fatty acids are expressed as a percentage $(w / w)$ of the $C_{18}$ unsaturated fatty acids; the figures in parentheses are the percentages $(w / w)$ based on the total fatty acids. M., Male; F., female.

Origin of fat

Fat from abdominal cavity $\mathbf{M}$.

$$
\text { F. }
$$

'Yellow fat' Mixed M. \& F.

Liver M.

F.

Kidney M.

F.

Longissimus dorsi $\mathbf{M}$.

F.

Liver M.

F.

Kidney M.

F.

\begin{tabular}{|c|c|c|}
\hline \multicolumn{2}{|c|}{ Conjugated } & Non- \\
\hline Diene & Triene & Diene \\
\hline \multicolumn{3}{|c|}{ (a) 'Glycerides' } \\
\hline $\begin{array}{c}0.9 \\
(0 \cdot 6)\end{array}$ & $\begin{array}{c}0 \cdot 1 \\
(0 \cdot 1)\end{array}$ & $\begin{array}{c}13 \cdot 8 \\
(8 \cdot 6)\end{array}$ \\
\hline $\begin{array}{c}0 \cdot 1 \\
(0 \cdot 1)\end{array}$ & Trace & $\begin{array}{c}16 \cdot 2 \\
(10 \cdot 6)\end{array}$ \\
\hline $\begin{array}{c}1 \cdot 2 \\
(0 \cdot 7)\end{array}$ & $\begin{array}{c}0 \cdot 1 \\
(0 \cdot 1)\end{array}$ & $\begin{array}{l}13.7 \\
(8 \cdot 7)\end{array}$ \\
\hline $\begin{array}{c}0 \cdot 2 \\
(0 \cdot 1)\end{array}$ & Trace & $\begin{array}{c}36 \cdot 4 \\
(13 \cdot 0)\end{array}$ \\
\hline $\begin{array}{c}0 \cdot 7 \\
(0 \cdot 3)\end{array}$ & $\begin{array}{c}0 \cdot 2 \\
(0 \cdot 1)\end{array}$ & $\begin{array}{c}33 \cdot 6 \\
(16 \cdot 1)\end{array}$ \\
\hline $\begin{array}{c}0 \cdot 6 \\
(0 \cdot 3)\end{array}$ & $\begin{array}{l}0 \cdot 1 \\
\text { (Trace) }\end{array}$ & $\begin{array}{l}14 \cdot 4 \\
(7 \cdot 1)\end{array}$ \\
\hline $\begin{array}{c}0 \cdot 2 \\
(0 \cdot 1)\end{array}$ & $\begin{array}{c}0 \cdot 2 \\
(0 \cdot 1)\end{array}$ & $\begin{array}{c}9 \cdot 2 \\
(5 \cdot 6)\end{array}$ \\
\hline $\begin{array}{c}0 \cdot 7 \\
(0 \cdot 3)\end{array}$ & $\begin{array}{l}0 \cdot 1 \\
\text { (Trace) }\end{array}$ & $\begin{array}{c}16 \cdot 0 \\
(8 \cdot 0)\end{array}$ \\
\hline $\begin{array}{c}5 \cdot 6 \\
(3 \cdot 1)\end{array}$ & $\begin{array}{c}0.5 \\
(0.3)\end{array}$ & $\begin{array}{c}6 \cdot 7 \\
(3 \cdot 7)\end{array}$ \\
\hline \multicolumn{3}{|c|}{ (b) Phospholipids } \\
\hline $\begin{array}{c}0 \cdot 5 \\
(0 \cdot 2)\end{array}$ & $\begin{array}{c}0 \cdot 1 \\
\text { (Trace) }\end{array}$ & $\begin{array}{c}62 \cdot 5 \\
(22 \cdot 5)\end{array}$ \\
\hline $\begin{array}{c}4 \cdot 3 \\
(1 \cdot 8)\end{array}$ & $\begin{array}{c}2 \cdot 0 \\
(0 \cdot 8)\end{array}$ & $\begin{array}{c}\mathbf{5 4 \cdot 4} \\
(22 \cdot 9)\end{array}$ \\
\hline $\begin{array}{c}0 \cdot 4 \\
(0 \cdot 2)\end{array}$ & $\begin{array}{l}0 \cdot 1 \\
\text { (Trace) }\end{array}$ & $\begin{array}{c}42 \cdot 1 \\
(16 \cdot 6)\end{array}$ \\
\hline $\begin{array}{c}0 \cdot 6 \\
(0 \cdot 3)\end{array}$ & Trace & $\begin{array}{c}34 \cdot 4 \\
(14 \cdot 8)\end{array}$ \\
\hline $\begin{array}{c}2 \cdot 6 \\
(0 \cdot 9)\end{array}$ & $\begin{array}{c}0 \cdot 3 \\
(0 \cdot 1)\end{array}$ & $\begin{array}{l}19 \cdot 9 \\
(6 \cdot 9)\end{array}$ \\
\hline $\begin{array}{c}0 \cdot 3 \\
(0 \cdot 1)\end{array}$ & Trace & $\begin{array}{c}34 \cdot 8 \\
(12 \cdot 2)\end{array}$ \\
\hline
\end{tabular}

Non-conjugated

Triene

$64 \cdot 3$
$(40 \cdot 4)$
$64 \cdot 2$
$(42 \cdot 2)$
$59 \cdot 3$
$(37 \cdot 7)$
$31 \cdot 0$
$(11 \cdot 0)$
$36 \cdot 5$
$(17 \cdot 5)$
$48 \cdot 8$
$(24 \cdot 1)$
$48 \cdot 8$
$(29 \cdot 9)$
$39 \cdot 9$
$(19 \cdot 8)$
$42 \cdot 0$
$(23 \cdot 1)$

$19 \cdot 0$

$(6 \cdot 8)$

16・1

$(6 \cdot 8)$

$11 \cdot 0$

(4.3)

$21 \cdot 5$

(9.2)

$10 \cdot 1$

(3.5)

$8 \cdot 8$

(3.1)
Oleic acid

(by diff.)

Triene

$\overline{\text { Diene }}$

$$
\begin{gathered}
20 \cdot 9 \\
(13 \cdot 1) \\
19 \cdot 5 \\
(12 \cdot 8) \\
25 \cdot 7 \\
(16 \cdot 3) \\
32 \cdot 4 \\
(11 \cdot 5) \\
29 \cdot 0 \\
(13 \cdot 9) \\
36 \cdot 1 \\
(17 \cdot 9) \\
41 \cdot 6 \\
(25 \cdot 5) \\
43 \cdot 3 \\
(21 \cdot 5) \\
45 \cdot 2 \\
(24 \cdot 8)
\end{gathered}
$$

4.38

3.94

3.99

$0 \cdot 85$

1.07

$3 \cdot 26$

$5 \cdot 21$

$2 \cdot 40$

3.45

$17 \cdot 9$

(6.4)

$23 \cdot 2$

(9.7)

$46 \cdot 4$

(18.3)

43.5

(18.7)

$67 \cdot 1$

(23.1)

$56 \cdot 1$

(19.7)
$0 \cdot 30$

0.31

$0 \cdot 26$

$0 \cdot 62$

0.46

$0 \cdot 25$ 
have indicated that the phospholipids contain more of the higher saturated $\left(\mathrm{C}_{18}\right.$ and above $)$ acids, and of $\mathrm{C}_{20}-\mathrm{C}_{22}$ unsaturated acids, but less palmitic and $\mathrm{C}_{16}$ unsaturated acids. In the present investigations these trends have been generally confirmed, but with certain exceptions. Contrary to expectation, the male and female liver 'glycerides' and the male kidney 'glycerides' contained respectively more of the $\mathrm{C}_{20}-\mathrm{C}_{22}$ unsaturated fatty acids, and more of the higher saturated $\left(\mathrm{C}_{18}\right.$ and above) fatty acids than the corresponding phospholipids, whereas the male and female longissimus dorsi ' glycerides' were lower in palmitic acid than the corresponding phospholipids. Previous investigations on the 'glycerides' and phospholipids of land mammals have been mainly confined to the liver tissues, and in this respect the rabbit conformed to the general pattern of exhibiting decreased proportions of palmitic acid, but increased amounts of stearic acid in the phospholipids as compared with the 'glycerides'. In the kidney and longissimus dorsi tissues, however, no marked differences in palmitic and stearic acid contents were noted between the 'glycerides' and phospholipids. In accordance with the findings for sheep, oxen, pigs and horses, the $\mathrm{C}_{20}-\mathrm{C}_{22}$ unsaturated fatty acids were found in substantial amounts in the 'glycerides' of the non-fatty tissues and in trace amounts only in glycerides of the fatty tissues.

In general, the corresponding lipids from the male and female rabbits showed similar fatty acid compositions, particularly in regard to the amount of palmitic acid. In some cases, however, there were differences, such as in the kidney 'glycerides', where the female rabbits showed lower proportions of $\mathrm{C}_{18}-\mathrm{C}_{20}$ saturated and $\mathrm{C}_{20}-\mathrm{C}_{22}$ unsaturated acids. In the liver phospholipids there was similarly considerably less $\mathrm{C}_{20}-\mathrm{C}_{22}$ unsaturated acids in the female rabbit than in the male.

The composition of the $\mathrm{C}_{18}$ unsaturated acids shows (see Table 3) that the triene (linolenic) acids concentrate in the 'glycerides' and the diene acids in the phospholipids. This is consistent with the earlier results (Shorland et al. 1952) for horse lipids. How ever, in the rabbit, the ratio $C_{18}$ triene/diene for the glyceride fractions covered a somewhat wider range, from 0.85 to $5 \cdot 21$ as compared with 2.17 to 4.22 found in the horse. Nevertheless, the ratio of $\mathrm{C}_{18}$ triene/diene was from 3 to 14 times higher in the glyceride fractions than in the corresponding phospholipid fractions. The glyceride fractions generally incorporated the $\mathrm{C}_{\mathbf{1 8}}$ diene and triene acids in much the same ratio as in the diet $\left(C_{18}\right.$ triene/ diene= about 4.0, Shorland et al. 1952), but very considerable selectivity was shown by the phospholipids. The present work substantiates the conclusions of Bruce \& Shorland (1951) that the selectivity of the phospholipids does not involve merely the selection of higher molecular weight fatty acids, but also the selection of fatty acids based on differences in unsaturation.

\section{SUMMARY}

1. The fatty acid composition of the 'glyceride' (non-phospholipid) and phospholipid fractions of the liver, kidney and longissimus dorsi, as well as that of the fatty tissues, of wild rabbits has been determined.

2. In accordance with previous investigations on other animals, the phospholipids generally contained more $\mathrm{C}_{18}$ and $\mathrm{C}_{20}$ saturated and unsaturated $\mathrm{C}_{20}-\mathrm{C}_{22}$ fatty acids than the corresponding ' $\mathrm{gly}$ cerides' but less palmitic and $\mathrm{C}_{16}$ unsaturated fatty acids. These differences, however, were not rigid, and exceptions are noted.

3. In agreement with the previous work on the horse lipids, the 'glycerides', as compared with the phospholipids, contained invariably more triene but less diene $\mathrm{C}_{18}$ unsaturated acids.

We wish to acknowledge with thanks the assistance of Mr C. N. Hooker and Mr A. S. Jessop in the analytical work.

The samples used in this work were supplied through the courtesy of Dr K. A. Wodzicki, Officer in Charge of the Animal Ecology Section, Department of Scientific and Industrial Research, Wellington, New Zealand.

\section{REFERENCES}

Bloor, W. R. (1943). The Biochemistry of the Fatty Acids, p. 246. New York: Reinhold Publ. Corp.

Borgström, B. (1952). Acta physiol. scand. 25, 101.

Brice, B. A. \& Swain, M. L. (1945). J.opt. Soc. Amer. 35, 532. Brooker, E. G. \& Shorland, F. B. (1950). Biochem. J. 46, 80. Bruce, L. W. \& Shorland, F. B. (1951). Nature, Lond., 167, 236.

Clément, G. \& Meara, M. L. (1951). Biochem. J. 49, 561.

Gupta, S. S. \& Hilditch, T. P. (1951). Biochem. J. 48, 137. Hilditch, T. P. (1956). The Chemical Constitution of Natural Fats, 3rd ed; pp. 91, 118, 615. London: Chapman and Hall Ltd.

Hilditch, T. P. \& Shorland, F. B. (1937). Biochem. J. 31, 1499.

Klenk, E. (1955). Hoppe Seyl. Z. 302, 268.

Oliver, A. P. \& Shorland, F. B. (1948). Biochem. J. 43, 18.

Reiser, R. (1950). J. Nutr. 42, 325.

Reiser, R. (1951). J. Nutr. 44, 159.

Shorland, F. B. (1939). Biochem. J. 33, 1935.

Shorland, F. B. (1950). Nature, Lond., 165, 766.

Shorland, F. B. (1951). N.Z. J. Sci. Tech. 33, 224.

Shorland, F. B. (1952). Nature, Lond., 170, 924.

Shorland, F. B. (1953). J. Sci. Fd Agric. 4, 497.

Shorland, F. B., Bruce, L. W. \& Jessop, A. S. (1952). Biochem. J. 52, 400.

Shorland, F. B. \& Hilditch, T. P. (1938). Biochem. J. $32,792$.

Shorland, F. B. \& Johannesson, D. L. (1951). Nature, Lond., 168, 75.

Widmer, C. jun. \& Holman, R. T. (1950). Arch. Biochem. 25, 1.

Witten, P. W. \& Holman, R. T. (1952). Arch. Biochem. Biophys. 41, 266. 